\title{
A Study of Selected Carbon Fractions in Soil under Arecanut Based Cropping Systems of Coastal Zone of Karnataka
}

\author{
V. Apurva*, Ganapathi and K.U. Mallesh
}

Department of Soil Science and Agricultural Chemistry, College of Agriculture, Navile University of Agricultural and Horticultural Sciences, Shivamogga-577204, Karnataka, India

*Corresponding author

\section{A B S T R A C T}

\section{Keywords \\ Carbon fractions, Areca nut based cropping systems \\ Article Info \\ Accepted: \\ 16 August 2018 \\ Available Online: \\ 10 September 2018}

\begin{abstract}
An investigation was undertaken at, Department of Soil Science and Agricultural Chemistry, College of Agriculture, UAHS, Shivamogga to a study of selected carbon fractions in soil under Areca nut based cropping systems of coastal zone (10) of Karnataka. Among the cropping systems studied, arecanut + mixed recorded higher mean potassium permanganate oxidizable organic carbon $\left(1387.33 \mathrm{mg} \mathrm{kg}^{-1}\right)$, cold water extractable carbon (391.63 $\left.\mathrm{mg} \mathrm{kg}^{-1}\right)$, total carbon $\left(23.52 \mathrm{~g} \mathrm{~kg}^{-1}\right)$, total organic carbon $\left(18.70 \mathrm{~g} \mathrm{~kg}^{-1}\right)$, total inorganic carbon $\left(0.0 .1618 \mathrm{~g} \mathrm{~kg}^{-1}\right)$ and soil microbial biomass carbon $\left(373.33 \mathrm{mg} \mathrm{kg}^{-1}\right)$ fractions as compared to other cropping systems and decreases with lower depth and carbon fractions were higher in $0-30 \mathrm{~cm}$ soil depth.
\end{abstract}

\section{Introduction}

Areca nut is growing as plantation crop in India besides it is an important cash crops in western and Eastern Ghats, east and north eastern regions of India. In areca nut based cropping system like pepper, cocoa, banana, zinger, turmeric, citrus, cardamom, medicinal and aromatic plants, flowers crops, coffee, etc. are the major crops generally growing as intercrop, mixed crop and high density multistorey crops. Higher soil loss, organic matter and nutrient loss is due to soil erosion and leaching of nutrients in coarse textured soil mainly with heavy rains. The yield level of areca nut, intercrops and mixed crops and soil fertility status are invariably depends upon the soil organic carbon status and nutrients management practices as well as other conservation strategies. Soil organic carbon status is the key to soil fertility, crop productivity and rising atmospheric temperature in the areca nut plantations of Western Ghats regions. Organic carbon is one of the five components of soil. During the process of soil formation, plant life begins to appear as soon as the products of weathering offer a suitable medium for its growth.

The vegetation so produced now take part in more intensive weathering and soil formation both during its growth and subsequently after it is incorporated with the mineral matter on completing its life cycle. The high organic 
carbon content in silvi system, eucalyptus and horti system, Areca nut might be due to litter fall. The highest amount of organic carbon content at the surface layers of the soil was due to the accumulation of organic matter in surface horizon and recycling of organic matter and also because of crop residues remaining in soil surface (Ashok, 1998).

\section{Materials and Methods}

The study will be covering coastal region of Karnataka, Dakshia Kannada and Udupi. The latitude and longitude coordinates of coastal region (Zone 10 ) are $12.520^{\circ} \mathrm{N} 74.500^{\circ} \mathrm{E}$.

A study was conducted at UAHS, Shivamogga to a study of selected carbon fractions in soil under Arecanut based cropping systems of coastal zone of Karnataka.

Soil samples will be collected from $0-30 \mathrm{~cm}$, $30-60 \mathrm{~cm}$ and $60-90 \mathrm{~cm}$ to study further distribution of soil carbon pools in lower depth $(60-90 \mathrm{~cm})$ of different areca nut based cropping systems.

Representative soil samples were collected from 0-30 cm, 30-90 cm and 60-90 cm depth from 2 location of different areca nut based cropping systems.

Selected carbon fractions were analysed by adopting standard procedure, determination of potassium dichromate oxidizable organic carbon was carried out by wet oxidation method by (Walkley and Black, 1934), potassium permanganate oxidizable organic carbon was carried out as per the procedure described by Blair et al., (1995), estimation of cold water extractable carbon (CWEC) was carried out as per the method described by McGill et al., (1986), the microbial biomass carbon (MBC) was analyzed by following chloroform fumigation method (Vance et al., 1987). Estimation of total carbon, total inorganic carbon and total organic carbon was carried out using total organic carbon (TOC) analyzer. The commonly used method is the catalytic combustion or oxidation method.

\section{Results and Discussion}

The soil organic carbon content decreased with depth in all areca nut based cropping Systems. The surface $(0-30 \mathrm{~cm})$ soil registered higher organic carbon content than subsurfaces i.e., 30-60 and 60-90 cm depths. Higher OC $\left(\mathrm{g} \mathrm{kg}^{-1}\right)$ in areca nut +mixed systems $\left(23.80 \mathrm{~g} \mathrm{~kg}^{-1}\right)$ in $0-30 \mathrm{~cm}$ and lower OC was observed in areca nut sole system (12.90 $\mathrm{g} \mathrm{kg}^{-1}$ ) decreases among the soil depth. Soil from Udupi show higher OC $\left(\mathrm{g} \mathrm{kg}^{-1}\right)$ in areca nut +cocoa systems $\left(19 \mathrm{~g} \mathrm{~kg}^{-1}\right)$ followed by areca nut +mixed $\left(19.00 \mathrm{~g} \mathrm{~kg}^{-1}\right)$ in $0-30 \mathrm{~cm}$ shown in Table 1 and lowest OC was observed in areca nut sole $\left(14.90 \mathrm{~g} \mathrm{~kg}^{-1}\right)$ system and decreases among the soil depth which is shown in Table 1.

In zone 10, Mangalore region show higher potassium permanganate oxidizable carbon (PPOC) in surface soil of Areca nut + Mixed systems $\left(1597 \mathrm{mg} \mathrm{kg}^{-1}\right)$ in 0-30 $\mathrm{cm}$ and lower was in areca nut sole (585. $\mathrm{mg} \mathrm{kg}^{-1}$ ) and which decreases in lower depths in all systems and soil from Udupi region show higher PPOC in $\left(1070.4 \mathrm{mg} \mathrm{kg}^{-1}\right)$ in areca nut +mixed in $0-30$ $\mathrm{cm}$ and lower was in areca nut + banana (715.1 $\mathrm{mg} \mathrm{kg}^{-1}$ ) decreases in lower depths in all systems, which is shown in Table 2 .

In Zone 10, Mangalore region show higher Cold water extractable carbon (CWEC) in surface soil of areca nut +mixed systems (426. $\mathrm{mg} \mathrm{kg}^{-1}$ ) in $0-30 \mathrm{~cm}$ and lower was in areca nut sole (312. $\mathrm{mg} \mathrm{kg}^{-1}$ ) and decreases in lower depth and soil from Udupi region show higher (399.2 $\mathrm{mg} \mathrm{kg}^{-1}$ ) in areca nut +mixed in 0-30 $\mathrm{cm}$ and lower was in areca nut+ banana (299.2 $\mathrm{mg} \mathrm{kg}^{-1}$ ) decreases among the soil depth which is shown in Table 3. 
Table.1 Soil organic carbon under different areca nut based cropping system of zone 10

\begin{tabular}{|c|c|c|c|c|c|}
\hline \multirow[t]{3}{*}{ District } & \multirow[t]{3}{*}{ Cropping systems } & \multicolumn{3}{|c|}{ SOC (g /kg) } & \multirow[t]{3}{*}{ Mean } \\
\hline & & \multicolumn{3}{|c|}{ Depth (cm) } & \\
\hline & & $0-30$ & $30-60$ & $60-90$ & \\
\hline \multirow[t]{5}{*}{ Mangalore } & Arecanut+Mixed & 23.80 & 10.90 & 17.00 & 17.23 \\
\hline & Arecanut+Banana & 17.70 & 8.10 & 13.60 & 13.13 \\
\hline & Arecanut+Pepper & 14.30 & 13.60 & 12.90 & 13.60 \\
\hline & Arecanut+Cocoa & 16.70 & 12.90 & 14.30 & 14.63 \\
\hline & Arecanut Sole & 12.90 & 8.80 & 8.80 & 10.16 \\
\hline Range & & $12.90-23.80$ & $8.80-13.60$ & 8.80-17.00 & \\
\hline Mean & & 17.08 & 10.86 & 13.32 & \\
\hline \multirow[t]{5}{*}{ Udupi } & Arecanut+Mixed & 19.00 & 13.60 & 8.80 & 13.80 \\
\hline & Arecanut+Banana & 19.00 & 10.90 & 16.30 & 15.40 \\
\hline & Arecanut+Pepper & 16.30 & 9.50 & 13.60 & 13.13 \\
\hline & Arecanut+Cocoa & 19.10 & 12.20 & 9.50 & 13.60 \\
\hline & Arecanut Sole & 14.90 & 6.00 & 9.50 & 10.13 \\
\hline Range & & $14.90-19.00$ & $6.00-13.60$ & $8.80-16.30$ & \\
\hline Mean & & 17.66 & 10.44 & 11.54 & \\
\hline
\end{tabular}


Table.2 Potassium permanaganate oxidizable carbon under different areca nut based cropping system of zone 10

\begin{tabular}{|c|c|c|c|c|c|}
\hline \multirow[t]{3}{*}{ District } & \multirow[t]{3}{*}{ Cropping systems } & \multicolumn{3}{|c|}{ PPOC (mg Kg $\left.{ }^{-1}\right)$} & \multirow[t]{3}{*}{ Mean } \\
\hline & & \multicolumn{3}{|c|}{ Depth (cm) } & \\
\hline & & $0-30$ & $30-60$ & $60-90$ & \\
\hline \multirow[t]{5}{*}{ Mangalore } & Arecanut+Mixed & 1597 & 1350 & 1215 & 1387.33 \\
\hline & Arecanut+Banana & 922.5 & 720 & 697.5 & 780 \\
\hline & Arecanut+Pepper & 717.75 & 612 & 567 & 632.25 \\
\hline & Arecanut+Cocoa & 650.25 & 699.7 & 582.7 & 644.21 \\
\hline & ArecanutSole & 585.1 & 517.5 & 509 & 537.20 \\
\hline Range & & 585.1-1597 & 517.5-1350 & $509-1215$ & \\
\hline Mean & & 894.52 & 779.84 & 714.24 & \\
\hline \multirow[t]{5}{*}{ Udupi } & Arecanut+Mixed & 1070.4 & 975 & 968.1 & 1004.50 \\
\hline & Arecanut+Banana & 715.1 & 675 & 634.5 & 674.86 \\
\hline & Arecanut+Pepper & 789.7 & 740.25 & 724.5 & 751.48 \\
\hline & Arecanut+Cocoa & 814.5 & 805.5 & 769.5 & 796.50 \\
\hline & Arecanut Sole & 717.7 & 657 & 627.4 & 667.36 \\
\hline Range & & 715.1-1070.4 & $657-975$ & 627.4-968.1 & \\
\hline Mean & & 821.48 & 770.55 & 744.8 & \\
\hline
\end{tabular}

Note:* PPOC- Potassium Permanaganate Oxidizable Carbon 
Table.3 Cold water extractable carbon under different arecanut based cropping system of zone 10

\begin{tabular}{|c|c|c|c|c|c|}
\hline \multirow[t]{3}{*}{ District } & \multirow[t]{3}{*}{ Cropping systems } & \multicolumn{3}{|c|}{ CWEC (mg Kg $\left.{ }^{-1}\right)$} & \multirow[t]{3}{*}{ Mean } \\
\hline & & \multicolumn{3}{|c|}{ Depth (cm) } & \\
\hline & & 0-30 & 30-60 & $60-90$ & \\
\hline \multirow[t]{5}{*}{ Mangalore } & Arecanut+Mixed & 426.1 & 397.8 & 351.0 & 391.63 \\
\hline & Arecanut+Banana & 381.1 & 376.5 & 351.0 & 369.53 \\
\hline & Arecanut+Pepper & 356.2 & 345.6 & 367.8 & 356.53 \\
\hline & Arecanut+Cocoa & 376.5 & 369.7 & 367.1 & 371.10 \\
\hline & Arecanut Sole & 312.6 & 305.8 & 332 & 316.80 \\
\hline Range & & $312.60-426.10$ & 305.80-397.80 & 332-367.8 & \\
\hline Mean & & 370.50 & 359.08 & 353.78 & \\
\hline \multirow[t]{5}{*}{ Udupi } & Arecanut+Mixed & 399.2 & 365.2 & 340.9 & 368.43 \\
\hline & Arecanut+Banana & 299.0 & 301.0 & 285.3 & 295.10 \\
\hline & Arecanut+Pepper & 303.2 & 286.5 & 266.5 & 285.40 \\
\hline & Arecanut+Cocoa & 377.4 & 374.4 & 361.4 & 371.06 \\
\hline & Arecanut Sole & 316.2 & 264.7 & 315.2 & 295.36 \\
\hline Range & & 299.0-399.2 & 264.7-374.4 & 266.5-361.4 & \\
\hline Mean & & 339.00 & 318.36 & 311.86 & \\
\hline
\end{tabular}


Table.4 Soil microbial biomass carbon under different arecanut based cropping system of zone 10

\begin{tabular}{|c|c|c|c|c|c|}
\hline \multirow[t]{3}{*}{ District } & \multirow[t]{3}{*}{ Cropping systems } & \multicolumn{3}{|c|}{ SMBC (mg Kg $\left.{ }^{-1}\right)$} & \multirow[t]{3}{*}{ Mean } \\
\hline & & \multicolumn{3}{|c|}{ Depth (cm) } & \\
\hline & & 0-30 & $30-60$ & $60-90$ & \\
\hline \multirow[t]{5}{*}{ Mangalore } & Arecanut+Mixed & 381 & 362 & 368 & 370.33 \\
\hline & Arecanut+Banana & 355 & 351 & 340 & 348.66 \\
\hline & Arecanut+Pepper & 371 & 321 & 311 & 334.33 \\
\hline & Arecanut+Cocoa & 340 & 334 & 322 & 332.00 \\
\hline & Arecanut Sole & 325 & 322 & 318 & 321.66 \\
\hline Range & & $325-381$ & 321-362 & 311-368 & \\
\hline Mean & & 354.4 & 338.8 & 331.8 & \\
\hline \multirow[t]{5}{*}{ Udupi } & Arecanut+Mixed & 379 & 372 & 369 & 373.33 \\
\hline & Arecanut+Banana & 312 & 310 & 310 & 310.66 \\
\hline & Arecanut+Pepper & 377 & 345 & 328 & 350.00 \\
\hline & Arecanut+Cocoa & 355 & 356 & 341 & 350.66 \\
\hline & Arecanut Sole & 341 & 333 & 306 & 326.66 \\
\hline Range & & 312-379 & 310-372 & 310-369 & \\
\hline Mean & & 352.8 & 343.2 & 344.8 & \\
\hline
\end{tabular}

Note: * SMBC- Soil Microbial Biomass Carbon

Table.5 TC $\left(\mathrm{g} \mathrm{kg}^{-1}\right)$ under different areca nut based cropping system of zone 10

\begin{tabular}{|l|}
\hline Zone10 \\
\hline \\
\hline Mean \\
\hline
\end{tabular}

\begin{tabular}{|l|}
\hline Cropping System \\
\hline Arecanut+Mixed \\
\hline Arecanut+Banana \\
\hline Arecanut+Pepper \\
\hline Arecanut+Cocoa \\
\hline Arecanut Sole \\
\hline
\end{tabular}

Note: *TOC- Total organic carbon

\begin{tabular}{|c|c|c|c|}
\hline \multicolumn{3}{|c|}{ TOC $\left(\mathrm{g} \mathrm{kg}^{-1}\right)$} \\
\hline Depth(cm) \\
\hline $\mathbf{0 - 3 0}$ & $\mathbf{3 0 - 6 0}$ & $\mathbf{6 0 - 9 0}$ & \\
\hline 23.4 & 20.3 & 12.4 & 18. \\
\hline 16.21 & 14.4 & 16.15 & 15.4 \\
\hline 14.25 & 13.2 & 12.85 & 13. \\
\hline 22.00 & 10.03 & 13.41 & 15. \\
\hline 10.80 & 9.40 & 7.70 & 9.3 \\
\hline $\mathbf{1 7 . 3 0}$ & $\mathbf{1 3 . 4 0}$ & $\mathbf{1 2 . 5 0}$ & \\
\hline
\end{tabular}

12.50

*TIC- Total inorganic carbon

\begin{tabular}{|c|c|c|c|}
\hline Mean & \multicolumn{3}{|c|}{ TIC $\left(\mathrm{g} \mathrm{kg} \mathrm{kg}^{-1}\right)$} \\
& $\mathbf{3 0 - 3 0}$ & $\mathbf{3 0 - 6 0}$ & $\mathbf{6 0 - 9 0}$ \\
\hline $\mathbf{1 8 . 7 0}$ & 0.1216 & 0.1257 & 0.1421 \\
\hline $\mathbf{1 5 . 5 0}$ & 0.1237 & 0.1532 & 0.2084 \\
\hline $\mathbf{1 3 . 4 0}$ & 0.1342 & 0.1253 & 0.1942 \\
\hline $\mathbf{1 5 . 1 0}$ & 0.1195 & 0.1244 & 0.1732 \\
\hline $\mathbf{9 . 3 0}$ & 0.1204 & 0.1302 & 0.1525 \\
\hline & $\mathbf{0 . 1 2 3 9}$ & $\mathbf{0 . 1 3 1 8}$ & $\mathbf{0 . 1 7 4 0}$ \\
\hline
\end{tabular}

*TC- Total carbon

\begin{tabular}{|c|c|c|c|}
\hline \multirow{2}{*}{ Mean } & \multicolumn{3}{|c|}{ TC $\left(\mathrm{g} \mathrm{kg}^{-1}\right)$} \\
\cline { 2 - 4 } & \multicolumn{3}{|c|}{ Depth(cm) } \\
\hline $\mathbf{0 . 1 2 9 8}$ & $\mathbf{0 - 3 0}$ & $\mathbf{3 0 - 6 0}$ & $\mathbf{6 0 - 9 0}$ \\
\hline $\mathbf{0 . 1 6 1 8}$ & 16.52 & 20.42 & 12.54 \\
\hline $\mathbf{0 . 1 5 1 2}$ & 14.38 & 14.55 & 16.35 \\
\hline $\mathbf{0 . 1 3 9 0}$ & 22.11 & 13.32 & 13.04 \\
\hline $\mathbf{0 . 1 3 4 4}$ & 10.92 & 9.53 & 13.58 \\
\hline & $\mathbf{1 7 . 4 5}$ & $\mathbf{1 3 . 5 9}$ & $\mathbf{1 2 . 6 1}$ \\
\hline
\end{tabular}


In zone 10, Mangalore region show higher Soil microbial biomass carbon(SMBC) in areca nut +mixed systems $\left(381 \mathrm{mg} \mathrm{kg}^{-1}\right)$ in 0 $30 \mathrm{~cm}$ and lower was observed in areca nut sole $\left(325 \mathrm{mg} \mathrm{kg}^{-1}\right)$ system and decreases in lower depth sand soil from Udupi show higher $\mathrm{MBC}$ in areca nut +mixed $(379 \mathrm{mg}$ $\mathrm{kg}^{-1}$ ) in $0-30 \mathrm{~cm}$ and lower was observed in areca nut +banana $\left(312 \mathrm{mg} \mathrm{Kg}^{-1}\right)$ and which decreases among the soil depth in all which is shown in Table 4.

In zone 10, Total organic carbon (TOC $\mathrm{g} \mathrm{kg}^{-1}$ ) was observed higher in surface soil of areca nut + mixed $\left(23.4 \mathrm{~g} \mathrm{~kg}^{-1}\right)$ and lowest was in areca nut sole $\left(10.8 \mathrm{~g} \mathrm{~kg}^{-1}\right)$ and decreases in lower depth. TIC was observed higher in areca nut +banana (0.2084) in $60-90 \mathrm{~cm}$ soils and lower was in surface soil of areca nut + cocoa $(0.1195)$ which is shown in Table 5.

In zone 10, Total carbon (TC) was observed higher in surface soil of areca nut + mixed (23.52 $\mathrm{g} \mathrm{kg}^{-1}$ ) and lower was observed in areca nut sole $\left(10.92 \mathrm{~g} \mathrm{~kg}^{-1}\right)$ and decreases in lower depth which is shown in Table 5.

The soil organic carbon content of surface soil (17.66 $\mathrm{g} \mathrm{kg}^{-1}$ )was higher than that of subsurface soil layer $\left(13.32 \mathrm{~g} \mathrm{~kg}^{-1}\right)$ which was due to higher litter fall and greater humification of soil organic carbon in surface soil (Geo Jose, 2006) The mean SOC value of areca nut +mixed show significantly higher value $\left(17.23 \mathrm{~g} \mathrm{~kg}^{-1}\right)$ and areca nut sole show lower mean SOC value $\left(10.13 \mathrm{gkg}^{-1}\right)$, among the different areca nut based cropping systems which is shown in Table 1.

In areca nut garden, due to the growth of weeds, less disturbance of soil and shading effect of the tree, there was relatively more accumulation of SOC than in soils under paddy and maize land use cover. These results are in conformity with results of Bayer and Bertol (2000).
Among the cropping systems, areca nut + mixed was recorded higher mean potassium permanganate oxidizable organic carbon (1387.33 $\mathrm{mg} \mathrm{kg}^{-1}$ ) and the lower mean potassium permanganate oxidizable organic carbon was observed under areca nut sole $\left(537.20 \mathrm{mg} \mathrm{kg}^{-1}\right)$. The range of PPOC value suggests that PPOC content increased in the beginning which decreased progressively with time. Such behavior indicates that this fraction changes with time because of its dynamic in nature. Application of organic sources with fertilizer significantly increased EOC content over fertilizer control. Verma et al., (2010) reported that labile pools of SOC were increased with increasing amount of added manures.

Among areca nut based cropping system and depths, areca nut+ mixed was recorded higher mean cold water extractable carbon $(391.63$ $\mathrm{mg} \mathrm{kg}$ ) and the lower mean cold water extractable carbon content was observed under areca nut sole $\left(295.36 \mathrm{mg} \mathrm{kg}^{-1}\right)$. This might be due to higher build-up of soil organic carbon, water soluble carbon and labile carbon on surface soil depth under areca nut+ mixed system might be attributed to the accumulation of litter fall on surface layer of soil. The subsequent decomposition and incorporation of litter into soil would have helped in raising the sol organic carbon pool status of soil (Gill et al., 1987).

Among the cropping systems, areca nut+ mixed was recorded higher mean $\mathrm{MBC}$ (373.33 $\mathrm{mg} \mathrm{kg}^{-1}$ ) and the lower mean MBC was observed under $\left(321.66 \mathrm{mg} \mathrm{kg}^{-1}\right)$ with. The variations in soil SMB-C among different areca nut based cropping system may be attributed to variation in soil organic matter content consequently the microbial activity. Further the variation in SOM may be attributed to variation in biomass return to soil and addition of manure. The variations in soil microbial biomass among different areca nut 
based cropping systems may be attributed to organic matter turnovers. Organic matter in the form of litter, compost or any other form serves as source of energy for soil microbes. Brij et al., (2012) reported highest SMBC under the forest and horticultural land use systems and attributed it to higher amount of substrate for proliferation of microorganisms.

Soils under areca nut+ mixed land use were recorded higher mean TOC $\left(18.70 \mathrm{~g} \mathrm{~kg}^{-1}\right)$ and the lower mean TOC was observed under soils of areca nut sole $\left(9.30 \mathrm{~g} \mathrm{~kg}^{-1}\right)$. This variation is due to the continuous cropping and soil cultivation has caused 47 per cent of soil organic carbon losses in the surface 0-15 $\mathrm{cm}$ depth, which is probably due to the rapid decomposition of native soil organic matter has been reported by Fayez (2006). Soils under areca nut+ Banana show higher mean of $\left(0.1618 \mathrm{~g} \mathrm{~kg}^{-1}\right)$ and the lower mean TIC was observed under soils of areca nut Sole $\left(0.1344 \mathrm{~g} \mathrm{~kg}^{-1}\right)$. TIC content varied widely among the cropping system, most of the total inorganic carbon is associated with calcium and magnesium carbonates.

In present study areca nut sole and banana recorded the lower TIC compare to other land use due to low $\mathrm{pH}$ (4.72) which was strongly acidic in nature which contains very low $\mathrm{Ca}$ and $\mathrm{Mg}$ carbonates compare to other land use cover Similar results was in accordance with Venkanna et al., (2014).

Soils from areca nut+ mixed recorded the higher TC (23.52 $\mathrm{g} \mathrm{kg}^{-1}$ ) and the lower mean TC was observed soil under areca nut Sole $\left(7.85 \mathrm{~g} \mathrm{~kg}^{-1}\right)$ the higher total carbon in areca nut+ mixed is due to higher litter fall in the system. Higher TC was observed under forest cover and areca nut land use due to high organic matter turn over, high rate of decomposition and minimal land disturbance, this result are similar in accordance with Dalal and Mayer (1986)
The soil organic carbon fractions were lower in Arecanut sole and Arecanut + mixed systems having higher organic carbon among different systems Carbon fractions were higher in $0-30 \mathrm{~cm}$ soil depth and decreases in lower depth of areca nut based cropping systems. So it can conclude that the soil carbon fraction properties significantly vary among different arecanut based cropping use systems.

\section{References}

Ashoka, 1998, Studies on properties of an Alfisols under selected forest plantation M. Sc. Agric. Thesis, Univ. Agric. Sci., GKVK, Bengaluru (India)

Bayer, C. and Bertol, I., 2000, Caracteristicas qufmicas de um cambissolo humico afetadas por sistemas de preparo com enfase a material organica. Rev. Bras. Cienc. Solo. 23: 687-694.

Blair, G. J., Lefroy, R. D. B. and Lisle, L., 1995, Soil carbon fractions based on their degree of oxidation, and the development of a carbon management index for agricultural systems. Aust. J. Soil Res., 46:1459-1466.

Brij, L. L., Manish, K. P., Pramod, J. and Biswas, A. K., 2012, Soil organic carbon pools and indices under different land use system in vertisols of central India. J. Indian Soc. Soil Sci., 60 (2): $125-131$.

Dalal, R. C. and Mayer, R. J., 1986, Long term trends in fertility of soils under continuous cultivation and cereal cropping in southern Queensland. I. Overall changes in soil properties and trends in winter cereal yields. Aust. J. Soil Res., 24: 265-279.

Geo Jose., 2006, Organic carbon distribution in soils under long term rice cropping systems in coastal and southern dry zones of Karnataka, M.Sc (Agri.) Thesis, Univ. Agric. Sci., Bangalore. 
Gill, H.S., Abrol, I.P. and Samra, J.S., 1987, Nutrient recycling through litter production in young plantations of Acacia nilotica and Eucalyptus tereticornis in a highly alkaline soil. For. Ecol. Mngt., 12: 57-69.

McGill, W. B., Cannon, K. R., Robertson, J. A. and Cook, F. D., 1986, Dynamics of soil microbial biomass and water soluble organic $\mathrm{C}$ in Breton L. after 50 years of cropping to two rotations. Can. J. Soil Sci., 66: 1-9.

Vance, E. D., Brookes, P. C. and Jenkinson, D. S., 1987, An extraction method for measuring soil microbial biomass carbon. Soil Biol. Biochem., 19:703707.

Venkanna, K., Uttam, K. M., Solomon Raju, A. J., Sharma, K. L., Ravikant, V., Adake, Pushpanjali, B., Sanjeeva,
Reddy., Rahul, N., Masane, Venkatravamma, K. and Peda Babu B., 2014, Carbon stocks in major soil types and land-use systems in semiarid tropical region of southern India. Curr. Sci., 106(4): 604-611.

Verma, B. C., Datta, S. P., Rattan, R. K. and Singh, A. K., 2010, Effect of temperature, moisture and different nitrogen sources on organic carbon pools and available nutrients in an alluvial soil. J. Indian Soc. Soil Sci., 59(3): 286-294.

Walkley, A. and Black, I. A., 1934, An examination of the Digestion method for determining soil organic matter and a proposed modification of the chromic acid titration method. Soil Sci., 37:2938.

\section{How to cite this article:}

Apurva, V., Ganapathi and Mallesh, K.U. 2018. A Study of Selected Carbon Fractions in Soil under Arecanut Based Cropping Systems of Coastal Zone of Karnataka. Int.J.Curr.Microbiol.App.Sci. 7(09): 2184-2192. doi: https://doi.org/10.20546/ijcmas.2018.709.269 